\title{
Antiplasmodial and Antioxidant Activities of Phyllanthus Species and Associated Medicinal Plants from Kenge in the Democratic Republic of Congo (DRC)
}

\author{
Oscar Nsendo Mwangu-Kabi, Rufin Kikakedimau Nakweti, and Sébastien Luyindula Ndiku
}

\section{ABSTRACT}

The aims of this work are firstly to carry the antiplasmodial and antioxidant activities of hydromethanolic extracts of three Phyllanthus species and these of two associated plants in order to establish difference firstly between Phyllanthus species and secondarily, between Phyllanthuis species and associated plants. These activities could be explained by plant secondary metabolites; thus, the phytochemical screening was previously carried out using some reagents and the total phenolics and the total flavonoids contents determined using standard chemical compounds for establishing curves. In finally, the relationship established between antiplasmodial activities and antioxidant activities. Results obtained in this work showed that flavonoids are present in Phyllanthus species but absent in both associated plants which contained saponins, steroids and triterpens that missing in Phyllanthus species. Concerning the total flavonoid content, $P$. niruroides showed high value $(0.75 \pm 0.03 \mathrm{mg} \mathrm{GAE} / \mathrm{g}$ of dry extract) than all total flavonoid content values of other plants. For total phenolic content, $P$. odontadenius showed high value with $0.07 \pm 0.01 \mathrm{mg} \mathrm{QE} / \mathrm{g}$ of dry extract than of two others phyllanthus species and the two associated plants which presented $0.06 \mathrm{mg} \mathrm{QE} / \mathrm{g}$ of dry extract. Antiplasmodial activities showed values from 13.2 $\pm 0.0 \mu \mathrm{g} / \mathrm{mL}$ for $P$. muellerianus to $102.65 \pm 0 \mu \mathrm{g} / \mathrm{mL}$ for associated plants. Phyllanthus species showed promising antiplasmodial activity or moderate antiplasmodial activity and the associated plants showed low antiplasmodial activity. The percentage inhibition of radicals could be explaining the high antioxidant activities for Phyllanthus species in comparison with associated plants with $P$. odontadenius which presented low value $(1.83 \pm 0.05 \mu \mathrm{g} / \mathrm{mL})$ and it is also the same for the ABTS radical where $P$. niruroides showed high value $(0.24 \pm 0.02 \mu \mathrm{g} / \mathrm{mL})$ than $H$. acida and $D$. englerianum. The established relationship shows that with the high antiplasmodial activities, the report in percentage between antiplasmodial activity and antioxidant activities is also high i.e., $15.61 \%$ for $P$. muellerianus.

Keywords: Antioxidant activity, antiplasmodial activity, free radicals, Phyllanthus sp., medicinal plants.

\section{INTRODUCTION}

Oxidative stress is defined as the imbalance between the generation of reactive oxygen species and the body's ability to neutralize and repair oxidative damage [1], [2] and [3].

Highly reactive to biological molecules such as proteins, lipids, carbohydrates and nucleic acids, reactive oxygen species can cause irreversible damage to the metabolic functions and structures of these substances. This danger is accentuated by the multiplicity of free radical source formation $\left(\mathrm{ROO}^{\circ}, \mathrm{RO}^{\circ}, \mathrm{OH}^{\circ}\right)$. It is believed that free radicals are produced during the formation of peroxides from fatty acids containing double bonds spaced apart by methylene groups such as those found in naturally occurring polyunsaturated fatty acids. The peroxidation of lipids exposed to oxygen is responsible not only for the food
Published Online: December 28, 2020

ISSN: 2684-5199

DOI: $10.24018 /$ ejbio.2020.1.6.126

Oscar Nsendo Mwangu-Kabi

Laboratory of Techniques Section, Higher Institute of Medical Techniques (ISTMKinshasa), DRC.

(e-mail: oscarnsendo@gmail.com) Rufin Kikakedimau Nakweti * Division of Life Sciences, General Commissariat for Atomic Energy/Regional Center for Nuclear Studies of Kinshasa (CGEA/CREN-K), University of Kinshasa, Democratic Republic of the Congo (DRC).

Department of Biology - Chemistry, Exacts Sciences Section, Higher Institute of Education (ISP-KENGE), DRC. (e-mail: frankciakika@gmail.com) Sébastien Luyindula Ndiku

Division of Life Sciences, General Commissariat for Atomic Energy/Regional Center for Nuclear Studies of Kinshasa (CGEA/CREN-K), University of Kinshasa, Democratic Républic of the Congo (DRC). (e-mail: sluyindula@yahoo.fr)

*Corresponding Author deterioration (rancidity), but also for tissue damage, in vivo, where it would be the cause of cancer, inflammatory diseases, atherosclerosis, and aging [4]. A free radical is defined as any molecule having one or more unpaired electrons [5] and [6]. Such a molecule is very unstable and reacts quickly with other components, capturing the electron necessary to acquire stability. The most devastating radicals in biological systems are the free radical oxygen species, sometimes called Reactive Oxygen Species (ROS), including the superoxide anion $\mathrm{O}_{2}{ }^{\circ}$, hydroxyl $\mathrm{OH}^{*}$, and peroxyl $\mathrm{O}_{2} \mathrm{H}^{*}$. A chain reaction begins when a free radical attack the nearest stable molecule by snatching its electron, and the attacked molecule itself becomes a free radical [7]. Tissue damage, such as peroxidation of the lipid membrane, formation of the disulfide bond and damage to DNA, caused by free radical oxygen is often referred to as 
oxidative damage. Factors that protect against damage by free radical oxygen are called antioxidants.

Free radical damage can cause DNA damage that leads to hereditary mutations and cancer, auto-immune disease, and atherosclerosis. By thus revealing abnormal biological molecules and by overexpressing certain genes, oxidative stress will also be the main initial cause of several other diseases, even accelerated aging [8], [9].

Human beings have, as part of their activities, an enzymatic system consisting mainly of hydroperoxidases including superoxide dismutase (SOD), catalase and glutathione peroxidase (GPx) which they use as antioxidants. SOD protects aerobic organisms against the potential deleterious effects of superoxide, catalase which has peroxidase activity and is also capable of using two molecules of $\mathrm{H}_{2} \mathrm{O}_{2}$ where one acts as an electron donor substrate and the other, as an oxidizer or electron acceptor. The role of catalase is to destroy hydrogen peroxide formed by the action of oxidases. Glutathione peroxidase (GPx) catalyzes the destruction of $\mathrm{H}_{2} \mathrm{O}_{2}$ and lipid hydroperoxides by converting reduced glutathione to its oxidized form, thereby protecting membrane lipids and hemoglobin from oxidation by peroxides [4], [10]. These enzymes have a complementary action on the radical cascade at the level of superoxide $\left(\mathrm{O}^{*}\right)$ and hydrogen peroxide $\left(\mathrm{H}_{2} \mathrm{O}_{2}\right)$, ultimately leading to the formation of water and molecular oxygen [11].

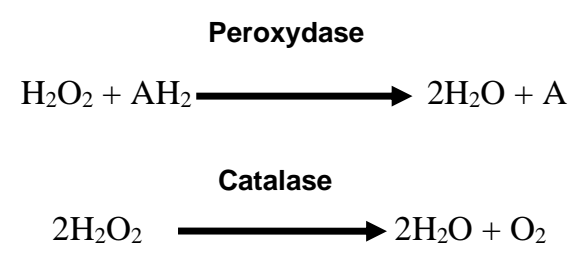

In addition to these enzymes playing the role of endogenous antioxidants, many molecules from our diet, including vitamins used as natural antioxidants, such as $\alpha$ tocopherol (vitamin E) and vitamin A which have a potential role in the prevention of atherosclerosis and cancer as well as vitamin $\mathrm{C}$, nutrients $(\mathrm{Cu}, \mathrm{Zn}, \mathrm{Se}, \mathrm{Mn}, \mathrm{Fe}$ etc.), natural compounds, etc. are considered to be antioxidants that act as scavengers for free radicals and thus reduce the toxicity of oxygen. Propyl gallate, butylhydroxyanisol (BHA) and butylhydroxytoluene (BHT) are antioxidants used as food additives.

Besides other important secondary metabolites (alkaloids, terpenes, etc.) used in pharmacies, many phenolic compounds of plant origin can play a role in human health [12], [13]. The plant kingdom, with the countless species of medicinal plants it contains, represents an important source of bioactive compounds which contribute to the main defense mechanisms against dioxygen, free radicals and ROS produced during photosynthesis [13]. These bioactive compounds are naturally present in fruits, flowers, seeds, or vegetative apparatus of many plants and are provided in humans through food (fruits and vegetables) or in foods derived from these plants (milk from soy, beer, wine, tea, chocolate
...). Some of these compounds could prove useful for human food and health.

Carotenoids and polyphenols constitute large families of compounds (several hundred) playing the role of natural antioxidants including $\beta$-carotene, caffeic acid and quercetin. Carotenoids and polyphenols are generally good scavengers of hydroxyl ${ }^{\circ} \mathrm{OH}$ and peroxyl $\mathrm{RO}_{2}{ }^{\cdot}$ radicals. They are therefore capable of inhibiting lipid peroxidation chains, but in a less efficient manner than that of $\alpha$ tocopherol. In addition, carotenoids have a specific role of singlet oxygen scavenger ${ }^{1} \mathrm{O}_{2}$, which allows them to exercise protection against damage induced by the ultraviolet rays of sunlight [14].

Studies on the antiplasmodial activities of Phyllanthus species have shown promise [15], [16], [17] and research on the effects of secondary metabolites contained in different plants would still prove beneficial in preventing lesions which would be due to free radicals. It is with this in mind that we undertook this study, on the one hand, to justify the use of Phyllanthus species and associated plants in traditional therapy and, on the other hand, to verify whether the plant extracts under study could reveal the antioxidant and antiradical activities that can be used for human health.

\section{MATERIALS AND METHODS}

\section{A. Plant Materials and Extraction}

Aerial parts of Phyllanthus species (P. muellerianus (O. Ktze.) Exell, $P$. niruroides Müll. Arg.and $P$. odontadenius Müll. Arg.) and two associated plants (Hymenocardia acida T. and Dialium englerianum H.) were collected by Rossy Munongo and Jules Muzingu from Kenge's city in 2018 and maintained at room temperature in bottles at the Life Science Division Laboratories in CGEA/CREN-K. Plant materials were previously reduced to powder using THOMAS SCIENTIFIC moulinex. Plant extracts were prepared by macerating $25 \mathrm{~g}$ of dried and powdered aerial parts in hydro-methanolic solution $(80 \%)$ at room temperature for about $48 \mathrm{~h}$. The materials were extracted, and the filtrates were evaporated to dryness under reduced pressure with a rotary evaporator $\left(\right.$ Rotavapor $^{\circledR}$ ) at $30^{\circ} \mathrm{C}$.

\section{B. Preparation of Plant Methanolic Extracts}

We carried out macerations at $80 \%$ in methanol $(25 \mathrm{~g}$ in $250 \mathrm{~mL}$ ) for $48 \mathrm{~h}$ at laboratory temperature. After filtration, the mixture was evaporated to dryness in an oven until complete drying. Then, we prepared $10 \mathrm{mg} / \mathrm{mL}$ methanolic solutions for each extract for the qualitative tests, in particular by TLC, $1 \mathrm{mg} / \mathrm{mL}$ solutions for the quantitative tests, $10 \%$ aqueous and chloroform solutions for chemical screening by reactions in solutions.

\section{Phytochemical Analysis}

\section{Phytochemical Screening}

Five $\mathrm{g}$ of each plant dissolved in distilled water $(50 \mathrm{~mL})$ and then boiled at $100{ }^{\circ} \mathrm{C}$ for $15 \mathrm{~min}$ and to leave to cool before filtered. Extracts were using for chemical screening; alkaloids were detected with Draggendorff's and Mayer's reagents [18]. Alkaloids were detected with Bouchardât, Draggendorff's and Mayer's reagents. Flavonoids were 
detected using Shinoda's reagent or cyanidine reagent [18]. Saponins were detected by the foam test [19]. Presence of tannins were detected using ferric chloride $1 \%$ reagent, Stiasny reagent and the Bate-Smith test [20], [21]. Anthraquinones were detected using Bornträger's reagent. Anthocyanins were identified using $\mathrm{HCl} 20 \%$, heating first before addition of isoamylic alcohol. Steroids and terpenoids were identified using Liebermann-Bouchard's reagent. Reducing sugars in the samples were determined using the Fehling's liquor (solution A: $\mathrm{CuSO}_{4} 4 \mathrm{~g}+$ distilled water $100 \mathrm{~mL}$; solution B: Seignette salt $20 \mathrm{~g}+\mathrm{NaOH} 12 \mathrm{~g}$ + distilled water $100 \mathrm{ml}$; to be mixed at equal volume) at hot gives a brick red precipitate. In the $2 \mathrm{~mL}$ of extract, 1 $\mathrm{mL}$ of Fehling's liquor, then heated the tubes containing the extracts to water bath at $90{ }^{\circ} \mathrm{C}$ for $30 \mathrm{~min}$. The appearance of a brick red precipitate indicates the presence of reduced sugars in the extracts. For the determination of free amino acids, $2 \mathrm{~mL}$ of the aqueous extract were placed in a test tube, $1 \mathrm{~mL}$ of the $2 \%$ methanolic ninhydrin solution was added thereto. The mixture was heated in a boiling water bath for $3 \mathrm{~min}$. The appearance of a blue to purple color indicates the presence of amino acids in the extract. The presence of alkaloids, flavonoids and terpenoids-steroids was confirmed by TLC performed on silica gel plates $60 \mathrm{~F}_{254}$ $10 \times 10 \mathrm{~cm}$. Flavonoids were detected using AcOEt/CH ${ }_{3} \mathrm{COOH} / \mathrm{HCOOH} / \mathrm{H}_{2} \mathrm{O}(100 / 11 / 11 / 27)$ as mobile phase with NEU's reagent (1\% diphenyl boric acid ethanolamine complex, methanolic solution 1\%). Steroids and terpenoids were detected using chloroform/ethyl acetate mixture (20/30, v/v) and n-Hexane/MeOH (9/1, v/v) as mobile phases and Liebermann-Bouchard's reagent. After drying, the TLC plates were heated at $105^{\circ} \mathrm{C}$ for $10 \mathrm{~min}$ to intensify the spot colors [22]. Alkaloids were confirmed using $\mathrm{CHCl}_{3} / \mathrm{MetOH} / \mathrm{NH}_{4} \mathrm{OH}$ (9: 2: 0.5 , v:v:v) and EtOAc/Iso-PrOH/NH 3 (85: 15: 5, v:v:v) as mobile phases and the Draggendorff's as reagent.

\section{Determination of Total Phenolic Content}

The total phenolic content of the various extracts was determined by the Folin-Ciocalteu method adopted by [23] with some modifications. The estimation of the total phenolic content contained in the five extracts used $(P$. muellerianus, $P$. niruroides, $P$. odontadenius, $H$. acida and D. englerianum) is carried out by spectrophotometer assay, according to the method of [24]. This method is based on redox reactions, the Folin-Ciocalteu reagent, a yellow acid, is used as an oxidant; it consists of a mixture of phosphotungstic acid $\left(\mathrm{H}_{3} \mathrm{Pw}_{12} \mathrm{O}_{40}\right)$ and phosphomolybdic acid $\left(\mathrm{H}_{3} \mathrm{PMo}_{12} \mathrm{O}_{40}\right)$. During the oxidation of phenolic compouds, Folin is reduced to a blue mixture of tungsten oxide $\left(\mathrm{W}_{8} \mathrm{O}_{23}\right)$ and molybdenum $\left(\mathrm{Mo}_{8} \mathrm{O}_{23}\right)$ in the presence of sodium carbonate. The intensity of the coloring is proportional to the levels of phenolic compounds present in the extracts. A volume of $0.5 \mathrm{~mL}(1 \mathrm{mg} / \mathrm{mL})$ of each extract was mixed with $0.5 \mathrm{~mL}$ of Folin-Ciocalteu (10\%). After 3 min, $1 \mathrm{~mL}$ of sodium carbonate solution $(20 \%)$ are added. The mixture was incubated at room temperature in the dark for $1 \mathrm{~h}$ and the absorbance was read at $725 \mathrm{~nm}$ with a spectrophotometer. Gallic acid is used as a reference standard and prepared in concentration fro $150 \mu \mathrm{g} / \mathrm{mL}$ to $5 \mu \mathrm{g} / \mathrm{mL}$. The calibration line for gallic acid has been drawn. Results are expressed in micrograms of gallic acid equivalents per gram of dry extract (mg GAE/g of dry extracts) [23].

\section{Determination of Flavonoid Contents}

The total flavonoid content in plant extracts was determined by spectrophotometric method according to [25]. Methanolic solutions (1 $\mathrm{mg} / \mathrm{mL})$ for each plant extracts were added with $1 \mathrm{~mL}$ methanolic solution of $\mathrm{AlCl}_{3}$ (2\%) and the whole was well stirred. After the incubation for $1 \mathrm{~h}$ at room temperature and protected from light, absorbance was determined by the spectrophotometer at $415 \mathrm{~nm}$ on a spectrophotometer Thermo Genesys 10S UVVIS. Mixtures were prepared in triplicate for each analysis and average values are reported. The same procedure was done for the standard solution of quercetin in nine different dilutions (ranging from 0.4 to $200 \mu \mathrm{g} / \mathrm{mL}$ ). Quercetin solutions allowed establishment of the calibration line establishment. The blank solution was prepared with $1 \mathrm{~mL}$ of $\mathrm{MeOH}$. The content of flavonoids in each extract was expressed in $\mathrm{mg}$ equivalent of quercetin per gram of the dry extract of corresponding plants.

\section{Evaluation of Antioxidant Activities}

\section{Determination of DPPH Free Radical Scavenging Activity}

The scavenging activity of DPPH free radical of the methanolic extract plants was performed based on [26]. 0.1 $\mathrm{mL}$ of the methanolic extract plant was mixed with $1 \mathrm{~mL}$ of the methanolic solution of DPPH $(100 \mu \mathrm{L})$. The resulting mixture is then stored in the dark at room temperature for $20 \mathrm{~min}$. The absorbance is then measured at $517 \mathrm{~nm}$ against a control composed of $1 \mathrm{~mL}$ of the DPPH solution and 0.1 $\mathrm{mL}$ of methanol. Preparation of the samples is carried out under the same operating conditions. Gallic acid used as benchmark antioxidant was tested at the following concentrations: 0.036 to $18.18 \mu \mathrm{g} / \mathrm{mL}$. 3 repetitions are done for each concentration. The decrease in absorbance is measured with a spectrophotometer and the PI (percentage inhibition) is calculated according to the formula above [27].

2. Measurement of Antioxidant Activity by the ABTS Test

The method used was that described by [28]. An amount of $38.40 \mathrm{mg}$ of ABTS was previously dissolved in $10 \mathrm{~mL}$ of water before adding $6.75 \mathrm{mg}$ of potassium persulfate. During the implementation of this test, the colorless ABTS is first oxidized with potassium persulfate $\left(\mathrm{K}_{2} \mathrm{~S}_{2} \mathrm{O}_{8}\right)$ to form the cationic radical $\mathrm{ABTS}^{+\bullet}$ which colored to blue green. The resulting mixture was stored in the dark and at room temperature for $12 \mathrm{~h}$ before use. It was subsequently diluted with methanol to obtain an absorbance in the range of 0.7 at $734 \mathrm{~nm}$. The antioxidant activity was measured by adding $0.3 \mathrm{~mL}$ of a methanolic solution of the extract tested to 0.3 $\mathrm{mL}$ of the $\mathrm{ABTS}^{+\bullet}$ solution. The extracts were tested at the following concentrations: 0.45 to $231 \mu \mathrm{g} / \mathrm{mL}$. Quercetin used as benchmark antioxidant was tested at the following concentrations: 0.09 to $46.2 \mu \mathrm{g} / \mathrm{mL}$. The addition of an antioxidant compound causes the reduction of the $\mathrm{ABTS}^{+\cdot}$ radical to ABTS. Antioxidant activity is determined by the discoloration of the solution and is expressed as the percent inhibition (PI) of the absorbance at $734 \mathrm{~nm}$, the wavelength 
at which the $\mathrm{ABTS}^{+\bullet}$ radical has a characteristic absorption band [29]. The absorbance reading was taken after 2 min on a spectrophotometer at $734 \mathrm{~nm}$ using ethanol as a blank.

The absorbance was measured at $517 \mathrm{~nm}$ using a spectrophotometer Thermo Genesys 10S UV-VIS and was converted to percentage of antioxidant activity according to the following expression [26], [2]. Three absorbance measurements were taken for each concentration tested $(\mathrm{n}=$ 3):

$$
\mathrm{PI}=[(\mathrm{A} 0-\mathrm{A} 1) / \mathrm{A} 0] \times 100
$$

A0: absorbance of the DPPH ${ }^{\bullet}$ solution or of the $\mathrm{ABTS}^{+\bullet}$ solution, i.e.: absorbance of the $\mathrm{ABTS}^{+\bullet}$ or of the $\mathrm{DPPH}^{\cdot}$ solution after addition of the extract tested at given concentration and after given time.

\section{E. In Vitro Antimalarial Activity}

Antimalarial activity assays were performed at the National Institute of Biomedical Research (INRB) in Kinshasa/Gombe, DR. Congo. The stock solutions were 1 $\mathrm{mg} / \mathrm{mL}$ hydro-methanolic extracts. Clinical isolates of $P$. falciparum were obtained from symptomatic malaria children (0-5 years) with high parasitaemia and, who did not receive antimalarial treatment in the three weeks preceding the diagnosis. After having had the relative abundance of parasites estimated at more than ten trophozoites per microscopic field (high parasitaemia) according to WHO and the National Malaria Control Program (NMCP). KIMBONDO Pediatric Hospital (Mama Koko) in Ngaliema commune (Kimbondo district) was our site for blood samples. Venous blood samples $(4 \mathrm{~mL})$ were collected in tubes containing $1 \%$ heparin and centrifuged for $5 \mathrm{~min}$ at $3000 \mathrm{rpm}$ in Thermo Scientific HERAEUS LABOFUGE 200 for separate plasma and erythrocytes. 1 $\mathrm{mL}$ of erythrocytes was mixed with $9 \mathrm{ml}$ of RPMI 1640 containing $25 \mathrm{mM}$ HEPES, $25 \mathrm{mM}$ sodium bicarbonate and $10 \%$ of pooled human serum. After homogenization, $50 \mu \mathrm{l}$ of the suspension were distributed in each well of a spot plate containing decreasing concentrations of extracts and then were maintained in culture following [30] method. Quinine and artesunate were used as benchmark antiplasmodial controls and tested at the same concentrations. After $48 \mathrm{~h}$ of incubation, thin smears were made and stained with GIEMSA 5\% and parasitaemia were determined with the Zeiss Primo Star microscope (GmbH/Germany) [31], [32]. Inhibition of parasitaemia (percent) was calculated as following:

$$
\text { Inhibition }(\%)=(\mathrm{A}-\mathrm{B} / \mathrm{A}) \times 100
$$

where $\mathrm{A}$ is the parasitaemia in the negative control and $\mathrm{B}$, the parasitaemia in the treated plates bucket. The $\mathrm{IC}_{50}$ of each sample was obtained using the dose-response curves.

\section{F. Correlation between Antiplasmodial and Antioxidant Activities}

The correlation between antiplasmodial activities and antioxidant activities was calculated using the relation below:

$$
\mathrm{C}(\mathrm{Aa} / \mathrm{Ao})=(\mathrm{Ao} / \mathrm{Aa}) \times 100
$$

where $\mathrm{C}(\mathrm{Aa} / \mathrm{Ao})$ : correlation between antiplasmodial activity and antioxidant activity, Aa: Antiplasmodial activity, Ao: Antioxidant activity.

\section{G. Expression of Results and Statistical Analysis}

Statistical analyzes were performed by analysis of variance (ANOVA) followed by fisher and student tests. The difference was considered significant when $\mathrm{p}<0.05$ compared to the negative control. Data were statistically analyzed using Microsoft Excel and Origin 6.1 software. Data were statistically analyzed using Microsoft Excel and Origin 6.1 software.

\section{RESULTS}

\section{A. Yield of Extracts}

The results on the yield of the extracts relative to the dry matter are shown in Fig. 1.

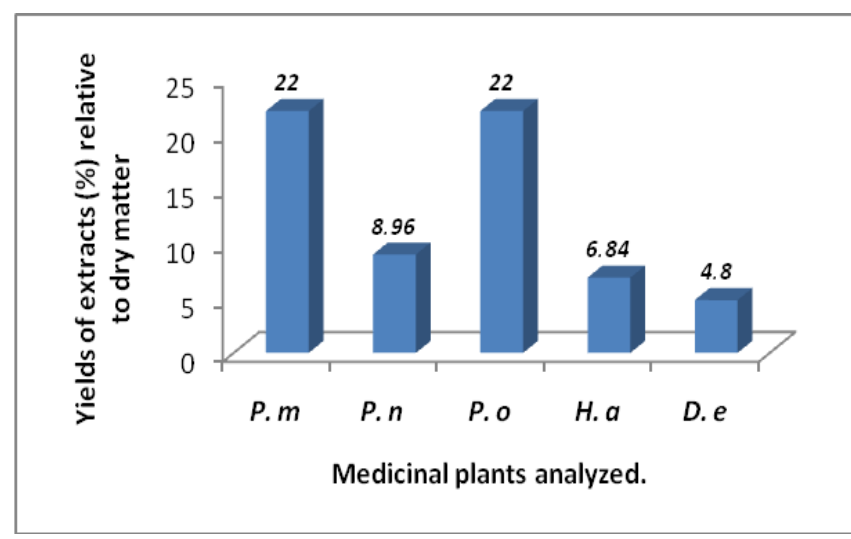

Fig. 1. Yields of extracts in relation to the dry matter. P. m: Phyllanthus muellerianus, P. n: Phyllanthus nirurö̈des, P. o: Phyllanthus odontadenius, H. a: Hymenocardia acida and D. e: Dalium englerianum.

It appears from Fig. 1 that the percentage yield of extracts is high for $P$. muellerianus and $P$. odontadenius with $22 \pm 0.87 \%$ and $22 \pm 1.37 \%$ respectively. D. englerianum with $4.80 \pm 0.27 \%$ showed poor yield of all. Statistically, $P$. muellerianus and $P$. odontadenius differ significantly at the $5 \%$ level to $P$. niruroides $(8.96 \pm 0.27 \%), H$. acida $(6.84 \pm 0.37 \%)$ and to $D$. englerianum. This difference could be explained by the number of secondary metabolites soluble in methanol $(80 \%)$ used as solvent.

\section{B. Phytochemical Analysis}

The results obtained on the phytochemical analyzes are shown in Table 1.

It emerges from Table 1 that flavonoids are present in Phyllanthus species and almost absent in $H$. acida and D. englerianum. On the other hand, anthocyanins, saponins, terpenoids and steroids are revealed in these two species and not found in the three species of Phyllanthus. Tannins and alkaloids are found in all plant species which studied in this work. 


\begin{tabular}{|c|c|c|c|c|c|c|}
\hline \multirow{2}{*}{$\begin{array}{c}\text { Chemical } \\
\text { groups }\end{array}$} & \multirow{2}{*}{ Reagents } & \multicolumn{5}{|c|}{ Plant extracts } \\
\hline & & $P . m$ & $P . n$ & P. $o$ & H. $a$ & D. $e$ \\
\hline Amino acids & $\begin{array}{c}\text { Ninhydrin } \\
\text { reagent }\end{array}$ & + & ++ & + & - & - \\
\hline Carbohydrates & $\begin{array}{c}\text { Alcohol } \\
\text { saturated with } \\
\text { thymol reagent }\end{array}$ & + & + & + & + & + \\
\hline \multirow[t]{2}{*}{ Flavonoids } & $\begin{array}{l}\text { Cyanidin } \\
\text { reagent }\end{array}$ & + & + & + & \pm & - \\
\hline & $\mathrm{NaOH} 10 \%$ & + & + & + & - & - \\
\hline Anthocyanins & $\mathrm{H}_{2} \mathrm{SO}_{4} / \mathrm{NH}_{4} \mathrm{OH}$ & \pm & - & - & + & + \\
\hline \multirow[b]{2}{*}{ Tannins } & $\mathrm{FeCl}_{3}$ & + & + & + & + & + \\
\hline & $\begin{array}{l}\text { Bâte-Smith } \\
\text { reagent }\end{array}$ & - & - & - & + & + \\
\hline $\begin{array}{l}\text { Reducing } \\
\text { sugars }\end{array}$ & $\begin{array}{l}\text { Fehling } \\
\text { reagent }\end{array}$ & \pm & - & - & + & + \\
\hline \multirow{3}{*}{ Alkaloids } & $\begin{array}{l}\text { Bouchardat } \\
\text { reagent }\end{array}$ & + & - & - & + & + \\
\hline & Mayer reagent & + & _- & _- & + & + \\
\hline & $\begin{array}{l}\text { Dragendorff } \\
\text { reagent }\end{array}$ & + & + & + & + & + \\
\hline Mucilages & $\begin{array}{c}\text { Absolute } \\
\text { alcohol }\end{array}$ & +++ & ++ & ++ & + & + \\
\hline Saponosides & Foam test & - & - & - & + & + \\
\hline $\begin{array}{l}\text { Sterols and } \\
\text { triterpenes }\end{array}$ & $\begin{array}{l}\text { Liebermann- } \\
\text { Bouchardât } \\
\text { reagents }\end{array}$ & - & - & - & + & + \\
\hline
\end{tabular}

Legend: P. m: Phyllanthus muellerianus, $P$. $n$ : Phyllanthus niruroïdes, $P$. o: Phyllanthus odontadenius, H. a: Hymenocardia acida and D. e: Dalium englerianum.

\section{Total Flavonoid and Total Polyphenol Contents}

The results obtained on the spectrophotometric assay of flavonoids and polyphenols are shown in Fig. 2.

The Fig. 2 show that $P$. niruroides has a high flavonoid content $(0.75 \pm 0.03 \mathrm{mg}$ EQ / $\mathrm{g}$ of dry sample) compared to all other plants; for the total polyphenol contents, it is $P$. odontadenius with $0.07 \pm 0.01 \mathrm{mg}$ EAG / g of dry sample) which has a high value. Statistically, there is no significant difference between the contents of flavonoids and polyphenols contained in the dry extracts of plants analyzed at the $5 \%$ confidence level.

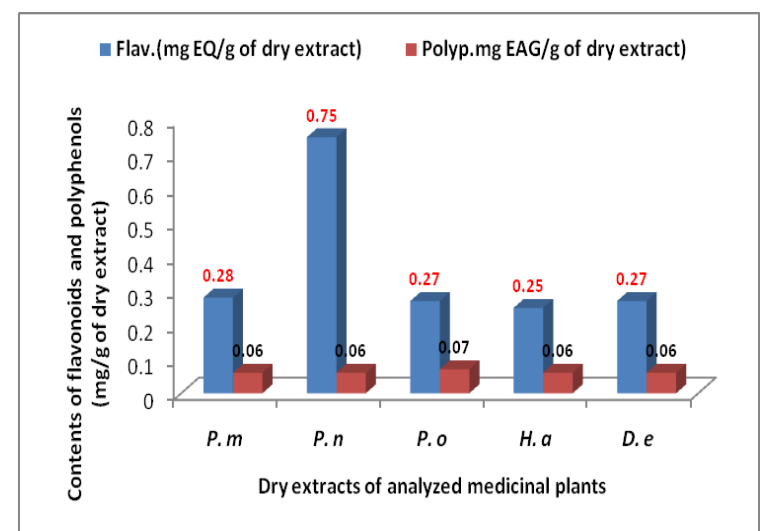

Fig. 2. Flavonoid and polyphenol content of the medicinal plant extracts analyzed. P. m: Phyllanthus muellerianus, $P$. $n$ : Phyllanthus niruroïdes, $P$. o: Phyllanthus odontadenius, H. a: Hymenocardia acida et D. e: Dalium englerianum.

\section{Antioxidant Potential of Plant Extracts}

The inhibition percentages (IP) of DPPH and ABTS radicals calculated as a function of the plants dry extracts are illustrated in Fig. $3 \mathrm{a}$ and $3 \mathrm{~b}$.
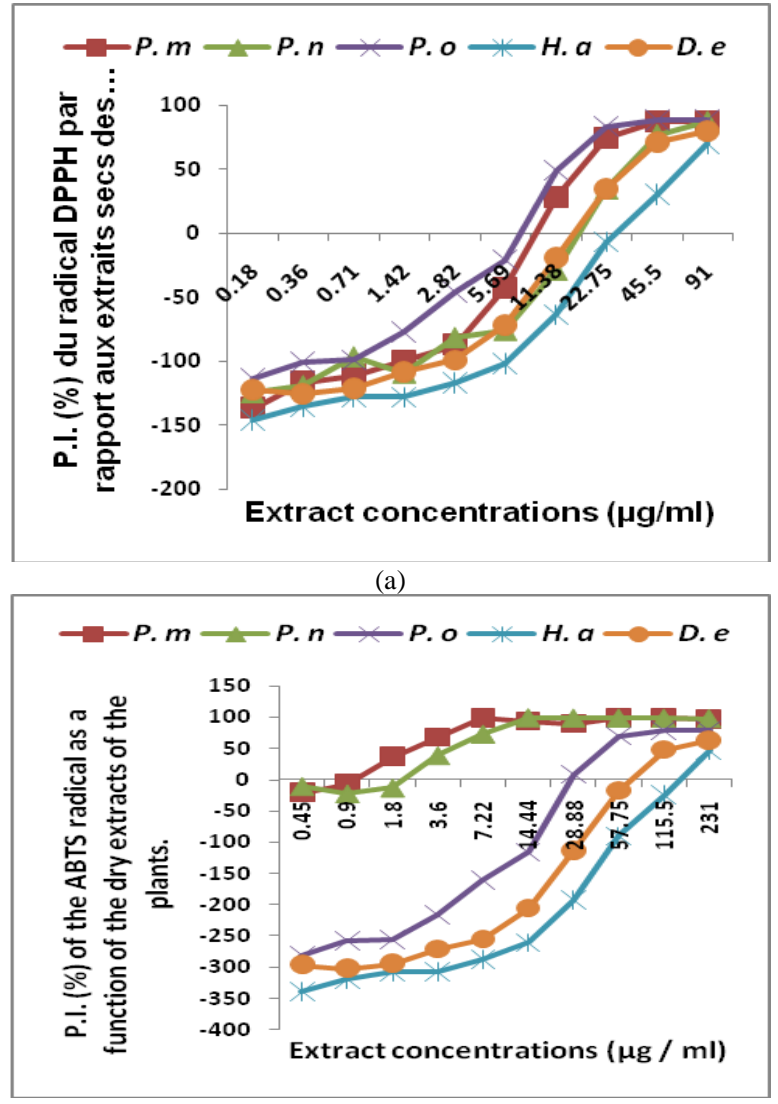

(b)

Fig. 3. Inhibition percentages of radicals: DPPH (a) and ABTS (b) relative to dry plant extracts. P. m: Phyllanthus muellerianus, $P$. $n$ : Phyllanthus niruroïdes, P. o: Phyllanthus odontadenius, H. a: Hymenocardia acida et D. e: Dalium englerianum.

With regard to Fig. $3 a$ and $3 b$, it emerges that the PIs of the DPPH and ABTS radicals as a function of the dry extracts of Phyllanthus species are generally higher than those of $H$. acida and $D$. englerianum. This fact is confirmed by the antioxidant activities (Fig. 4) of the extracts of Phyllanthus species on these radicals (DPPH and ABTS).

\section{E. In Vitro Free Radical Scavenging Activity}

The in vitro free radical scavenging activity of the methanolic extracts of plants on DPPH or ABTS is shown in Fig. 4.

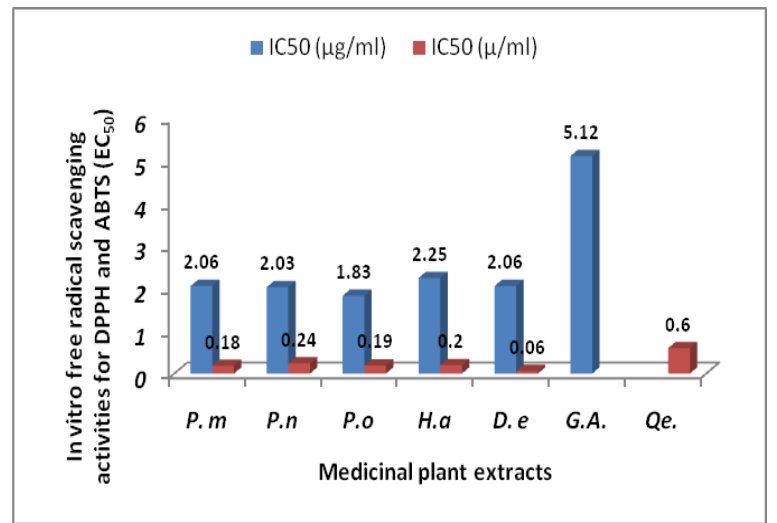

Fig. 4. In vitro free radical scavenging activities of DPPH and ABTS. $P$. $m$ Phyllanthus muellerianus, $P$. $n$ : Phyllanthus niruroïdes, $P$. o: Phyllanthus odontadenius, H. a: Hymenocardia acida et D. e: Dalium englerianum; G.A.: Gallic acid and Qe: Quercetin. 
Fig. 4 shows that the anti-free radical activity of ABTS is greater the higher the concentration. The antioxidant capacity for this test (ABTS) was expressed in Trolox equivalent (TEAC) which corresponds to the concentration of Trolox in $\mu \mathrm{g}$ giving the same activity as a milligram of the substance tested, the higher the TEAC, the more the extract is effective. To be able to calculate the TEAC, a calibration curve is produced with the Trolox and the results obtained are given in $\mu \mathrm{g} / \mathrm{mL}$ Trolox $/ \mathrm{mg}$ equivalent. It emerges that $P$. niruroides, with $\mathrm{IC}_{50}=0.24 \pm 0.02 \mu \mathrm{g} / \mathrm{mL}$, has a higher $\mathrm{IC}_{50}$ than all the other extracts and a high antioxidant activity also compared to all the extracts except for the control (Quercetin, $\mathrm{IC}_{50}=0.60 \pm 0.08 \mu \mathrm{g} / \mathrm{mL}$ ).

It is $P$. muellerianus with $\mathrm{IC}_{50}=0.18 \pm 0.05 \mu \mathrm{g} / \mathrm{mL}$ ) which exhibits low DPPH antioxidant activity compared to all extracts and compared to the control. Statistically, $D$. englerianum alone differs significantly at the 5\% level with all the medicinal plant extracts analyzed.

\section{F. In Vitro Antiplasmodial Activities and Report between Antiplasmodial And Antioxidant Activities}

The in vitro antiplasmodial activities and the correlation between antiplasmodial and antioxidant activities of plant extracts on the isolates of Plasmodium falciparum is shown in Fig. 5.

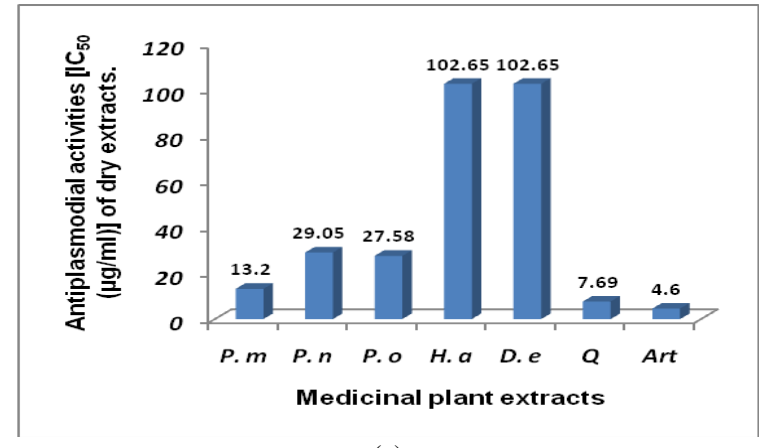

(a)

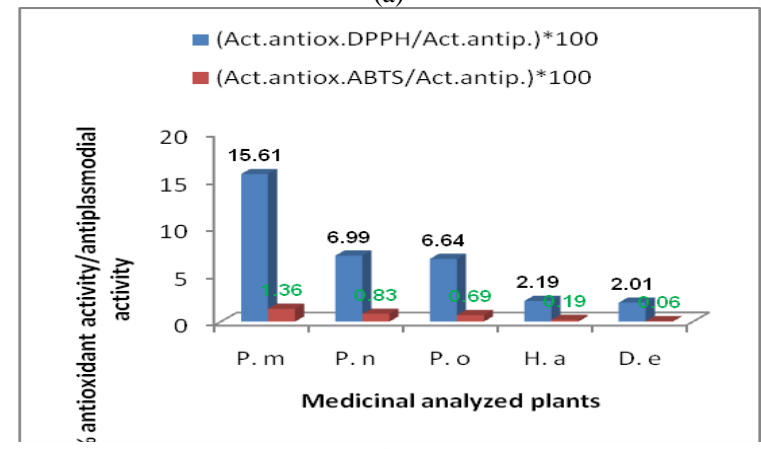

(b)

Fig. 5. Antiplasmodial activity of extracts from Phyllanthus species and two associated plants (a). Correlation between antiplasmodial activities and antioxidant activities (b). P. m: Phyllanthus muellerianus, $P$. $n$ : Phyllanthus niruroides, $P$. o: Phyllanthus odontadenius, $H$. $a$ : Hymenocardia acida et D. e: Dalium englerianum; Q: Quinine and Art: Artesunate.

With regard to Fig. 5a, it emerges that the extracts of $P$. muellerianus with $13.2 \pm 0.0 \mu \mathrm{g} / \mathrm{mL}$ showed promising antiplasmodial activity $\left(5 \mu \mathrm{g} / \mathrm{mL}<\mathrm{IC}_{50}<15 \mu \mathrm{g} / \mathrm{mL}\right)$ and the extracts of $P$. odontadenius $(27.58 \pm 0.12 \mu \mathrm{g} / \mathrm{mL})$ and those of $P$. niruroides $(29.05 \mu \mathrm{g} \pm 0.18 \mu \mathrm{g} / \mathrm{mL})$ show moderate antiplasmodial activity $\left(15 \mu \mathrm{g} / \mathrm{mL}<\mathrm{IC}_{50}<50 \mu \mathrm{g}\right.$
/ $\mathrm{mL}$ ) whereas extracts of $H$. acida and D. englerianum with $102.65 \pm 0 \mu \mathrm{g} / \mathrm{mL}$ showed a low antiplasmodial activity $\left(\mathrm{IC}_{50}>50 \mu \mathrm{g} / \mathrm{mL}\right)$. Statistically, there is a significant difference at the threshold of $5 \%, 1 \%$ and $0.1 \%$ between the different extracts. The extracts of $P$. odontadenius and $P$. niruroides did not show a significant difference at the $5 \%$ level. The same is true with the extracts of $H$. acida and $D$. englerianum. Fig.5b show that the report between antiplasmodial and antioxidant activities is in general high ( $15.61 \%$ for $P$. niruroides) with high antiplasmodial activity and weak with the weak antiplasmodial activity $(2.19 \%$ and $2.01 \%$ for $H$. acida and D. englerianum) concerning the DPPH radical. It's the same for the ABTS radical.

\section{DISCUSSION}

The metabolites found in this study in Phyllanthus species meet those previously found by [15], [33], [17] and [34]. [35] showed that Phyllanthus emblica contains flavonoids, alkaloids, tannins, saponins and glucosides, but this species of Phyllanthus does not contain carbohydrates, sterols and triterpenoids or free amino acids. Contrary to our results, only the sterols and triterpenoids which were found to be absent, whereas in $H$. acida and $D$. englerianum, it is only the flavonoids and the amino acids which are absent. These authors also report the contents of the total polyphenol $(99.52 \pm 1.91 \mathrm{mg}$ EAG / g of P.E extract), of flavonoid $(389.33 \pm 1.25 \mathrm{mg}$ EQ / $\mathrm{g}$ of PE extract) and of tannins $(310 \pm 0.21 \mathrm{mg}$ ECath./ $\mathrm{g}$ of PE extract), it emerges that their values are higher than those found for our samples which vary between $0.25 \mathrm{mg}$ EAG / $\mathrm{g}$ of dry extract to $0.75 \mathrm{mg}$ EQ / $\mathrm{g}$ of dry extract for flavonoids and $0.06 \mathrm{mg}$ EAG / g of dry extract to $0.07 \mathrm{mg}$ EAG / g of dry extract for total polyphenol content. Tannins have not been determined. Absence or presence of secondary metabolites could be explained also by possible disturbance or stimulation of genes involved in different biosynthesis pathways. These variations could be due to the solvent used and the geographic location of plant harvesting sites. The contents of flavonoids are also higher than those of polyphenols.

[36] who worked on the correlation between the antioxidants and anti-free radical activities of irradiated $P$. odontadenius extracts and their antiplasmodial activity showed that unirradiated $P$. odontadenius exhibits a stronger antioxidant activity $(3.61 \pm 0.15 \mu \mathrm{g} / \mathrm{mL})$ on the DPPH radical than those derived from extracts of plants irradiated with $14.44 \pm 1.26 \mu \mathrm{g} / \mathrm{mL}$ (Po-1503), $7.22 \pm 0.53 \mu \mathrm{g} / \mathrm{mL}$ (Po-1504) and 7.22 $\pm 087 \mu \mathrm{g} / \mathrm{mL}$ (Po1505) respectively. Unlike the ABTS radical, plant extracts from irradiated seeds exhibited better antioxidant activities with respectively $11.36 \pm 1.31 \mu \mathrm{g} / \mathrm{mL}$ (Po-1504), $11.36 \pm 1.63 \mu \mathrm{g} / \mathrm{mL}(\mathrm{Po}-1505)$ than the control plant with $5.68 \pm 0.88 \mu \mathrm{g} / \mathrm{mL}$.

The analysis carried out by [37] on the trapping of the DPPH radical in order to determine the antioxidant activities of the ethanolic extracts of Phyllanthus urinaria and its different fractions showed that the $\mathrm{IC}_{50}$ values vary according to the extracts and range from 4.22 to 
$1853.31 \mu \mathrm{g} / \mathrm{mL}$. Our results obtained on the methanolic extracts of our plants showed low values (from 1.83 to 2.25 $\mu \mathrm{g} / \mathrm{mL}$ ) compared to those found by [35] therefore exhibit a strong antioxidant activity on the trapping of the DPPH radical.

The complexity of crude extracts in polyphenolic substances and the synergy between them for better antioxidant activity has been reported by [12] and [38].

Boland and Tenhave postulated in 1947 that reactions where phenolic compounds interfere with the oxidation of lipids by relinquishing their hydrogens into lipid radicals, then which compete with propagation reactions [39]. The studies by [40], [41], [42] on cumin showed that the correlation coefficient between the content of cumin extracts in polyphenols and the antioxidant activity was very significant, indicating that $81 \%$ of the antioxidant capacity of the extracts were due to the intake of phenolic compounds. Our results obtained presently agree with this assertion because $P$. odontadenius with $0.07 \mathrm{mg} \mathrm{EGA} / \mathrm{g}$ of dry matter, presented more polyphenols than the other species and consequently also presents a better antioxidant activity on the $\mathrm{DPPH}^{\cdot}$ radical unlike the radical $\mathrm{ABTS}^{++}$for which $P$. niruroides was shown to be more active with 0.24 $\mu \mathrm{g} / \mathrm{mL}$. This fact could be explained by the high content of flavonoids $(0.75 \mathrm{mg} \mathrm{EQ} / \mathrm{g}$ of dry matter) that this plant contains. Flavonoids have many biological activities, and these activities are attributed in part to the antioxidant properties of these natural compounds [12]. The antioxidant action of flavonoids is not only exerted by the inhibition of free radicals, but it is also manifested by the neutralization of oxidative enzymes and by the chelation of metal ions responsible for the production of reactive species of the oxygen [43], [44]. Due to their low redox potentials, flavonoids are thermodynamically able to reduce oxidizing free radicals, such as superoxide, peroxyl, alkyl, and hydroxyl. They exert this action through hydrogen transfer and the resulting flavonoxy radical can react with another radical to form a stable structure [45].

It should be remembered here that the $\mathrm{IC}_{50}$ is inversely related to the antioxidant capacity of a compound, because it expresses the amount of antioxidant required to decrease the concentration of the free radical by $50 \%$. For the DPPH radical, the lower $\mathrm{IC}_{50}$ values indicate the efficiency of the extract and thus a strong antioxidant power, i.e., the lower the $\mathrm{IC}_{50}$ the more the extract has a powerful antioxidant potential, on the other hand, the anti-free radical activity of ABTS is all the more higher the higher the concentration [46], [47].

The correlation level between phenolic content and antioxidant activity is an interesting aspect, but it must be taken into account that phenolic compounds react differently in the analysis, in the on hand depending on the number of phenolic groups and, the other hand, total phenolic compounds aren't necessarily all incorporated among antioxidants that may be present in an extract [41].

The results obtained in this work meet the WHO standards [48], [49] according to which the antiplasmodial activity of an extract or a drug is high if $\mathrm{IC}_{50}<5 \mu \mathrm{g} / \mathrm{mL}$, promising $\left(\mu \mathrm{g} / \mathrm{mL} 5<\mathrm{IC}_{50}<15 \mu \mathrm{g} / \mathrm{mL}\right.$ ) for P. muellerianus with $13.2 \pm 0.0 \quad \mu \mathrm{g} / \mathrm{mL}$, moderate $\left(15 \mu \mathrm{g} / \mathrm{mL} \quad<\mathrm{IC}_{50}\right.$ $<50 \mu \mathrm{g} / \mathrm{mL})$ for $P$. odontadenius $(27.58 \pm 0.12 \mu \mathrm{g} / \mathrm{mL})$ and $P$. niruroides $(29.05 \mu \mathrm{g} \pm 0.18 \mu \mathrm{g} / \mathrm{mL})$ and the product is inactive if $\mathrm{IC}_{50}>50 \mu \mathrm{g} / \mathrm{mL}$ and this is the case of $H$. acida and D. englerianum with $102.65 \pm 0 \mu \mathrm{g} / \mathrm{mL}$. Considering the WHO standards taken up by [50], methanolic extracts of Phyllanthus species will be classified in active extracts $(5 \mu \mathrm{g} / \mathrm{mL}<\mathrm{IC} 50<50 \mu \mathrm{g} / \mathrm{mL})$ and the $H$. acida and $D$. englerianum extracts in inactive extracts $\left(\mathrm{IC}_{50}>100 \mu \mathrm{g} / \mathrm{mL}\right.$ ) compared to the ethanolic extracts of $P$. emblica and $P$. acidus which were classified as weakly active extracts $50 \mu \mathrm{g} / \mathrm{mL}<\mathrm{IC}_{50}<100 \mu \mathrm{g} / \mathrm{mL}$.

\section{CONCLUSION}

The reason for this study was to determine the antioxidant and the antiplasmodial activities of the methanolic extracts of Phyllanthus species and finally to establish a correlation between these two parameters. The phytochemical screening should provide a global view of the secondary metabolites responsible for acting on the two activities. And thus finally, justify the use of species of Phyllanthus and other associated species in traditional medicine. From the results obtained, it turned out that the species of Phyllanthus have greater antioxidant and antiplasmodial activities than the controls used and the associated species.

The DPPH free radical scavenging test shows that Phyllanthus odontadenius is the one of phyllanthus species whose extract has a very important antioxidant activity and even more than other phyllanthus species and the control (gallic acid) by fixing free radicals with a very effective concentration low $(1.83 \mu \mathrm{g} / \mathrm{mL})$. For the ABTS free radical, $P$. niruroides, one of phyllanthus specie, is also powerful antioxidant with high effective concentration and highest value than of quercetin. The species of Phyllanthus showed high antiplasmodial activities than the associated species (H. acida and D. englerianum) that showed less or weak fixation of DPPH free radical. These species showed also inactive extracts on Plasmodium falciparum in spite of the presence of secondary metabolites revealed.

With the composition of bioactive secondary metabolites contained in Phyllanthus species which also allow free radical scavenging, this could justify the use of Phyllanthus species in traditional medicine for the treatment of certain diseases.

\section{ACKNOWLEDGMENT}

Rossy Munongo and Jules Muzingu from Kenge's city who harvested plant samples. M. Dany SINZIDI, Laboratory assistant in Parasite Laboratory I in the INRB (Institut National de Recherche Biomédicale) for the In vitro antiplasmodial activities analysis. Professor Désiré MUSUYU for the supervion of the analysis antioxidant activities in MPI and Biochemistry \& hematology Laboratories in INRB. Thanks to Dr. Patrick Doumas for the correction of our final manuscript. All person who contributed to this work. 


\section{REFERENCES}

[1] G. Tirzitis and G. Bartosz, "Determination of antiradical and antioxidant activity: basic principles and new insights". Acta Biochimica Polonica, Vol. 57(1): 139 - 142, 2010 (Published September 2009).

[2] S.O. Sarr, A.D. Fall, R. Gueye, A. Diop, K. Diatta, N. Diop, B. Ndiaye and Y.M. Diop, «Etude de l'activité antioxydante des extraits des feuilles de Vitex doniana (Verbenacea)». Int. J. Biol. Chem. Sci. 9(3): pp. 1263-1269, June 2015.

[3] [3] A.M. Blandón, O.M. Mosquera, A.E.G. Sant'ana, A.F.Dos Santos, .L.L.S. Pires, "Antioxidant activity of plant extracts from Colombian Coffee-Growing Eco-Region”. Revista Facultad de Ciencias Básicas, Vol. 13 (1), pp. 56-59, February 2017.

[4] R.K. Murray, D.A. Bender, K.M. Botham, P.J. Kennelly, V.W. Rodwell and P.A. Weil, Biochimie de Harper. Nouveaux horizons, de Boeck, $5^{\text {ème }}$ Ed. Traduction de la $29^{\text {ème }}$ Edition américaine par Lionel Domenjoud, bruxelles, pp. 123-125 ; 154-155 ; 714-716, 2013.

[5] B. Jacques, and R. André, Biochimie métabolique. Ed ellipses. Paris. pp.: 217-219- 220-223-225, 2004.

[6] M. Guilloton, B. Quintard and P.-F. Gallet (2013): Mini manuel de Biochimie. $3^{\text {ème }}$ Dunod, Paris, chap.4, pp. $114-116$,

[7] M. Martinez-Cayuela, "Oxygen free radicals and human disease". Biochem.77: pp. 147- 161, January 1995 (Accepted September 1994).

[8] S. E. Atawodi, "Antioxidant potential of African plants". African J. of Biotec.4 (2): pp. 128- 133, February 2005.

[9] S.R. Georgetti, R. Casagrande, V. M. Di Mambro, E.C.S. Azzolini Ana and J.V. Fonseca Maria, "Evaluation of the antioxidant activity of different flavonoids by the chemiluminescence medhod". AAPS Pharm Sci. 5 (2): pp: 111-115, june 2003.

[10] N. Avissar, C. WhitinJ., and P.Z. Allen, "Plasma selenium-dependent glutathione peroxidase". J. Biol. Chem. 2: pp. 15850-15855, September1989.

[11] A. Marfak, «Radiolyse gamma des flavonoïdes : étude de leur réactivité avec les radicaux issus des alcools : formation de depsides ». Thèse de doctorat en Pharmacie : Sciences-BiologieSanté : Biophysique. Uiversité de Limoges (France), 199p, 2003.

[12] J.-J. Macheix, A. Fleuriet and C. Jay-Allemend, Les composes phénoliques des végétaux. Presses Polytechniques et Universitaires Romandes, Losanne, Italie, pp. 141 - 153, 2005.

[13] J.-F. Morot-Gaudry. and R. Prat, Biologie végétale. Croissance et dévéloppement. $2^{2 \mathrm{eme}}$ Ed., Dunod, Paris, 242p.

[14] M. Gardès-Albert, D. Bonnefont-Rousselot, Z. Zohreh Abedinzadeh and D. Daniel Jore, "Reactive oxygen species. How oxygen may become toxic?" L'actualité chimique: Mécanismes biochimiques, N²70. pp: 91-96, November - December 2003.

[15] L. Tona, N. Ngimbi, M. Tsakala, K. Mesia, R.K. Cimanga, S. Apers, T. De Bruyne, L. Pieters, J. Totté and A.J. Vlietinck, “Antimalarial activity of 20 crude extracts from nine African medicinal plants used in Kinshasa/congo". J. Ethnopharmacol. 68, pp. 193 - 203, May 1999.

[16] N. Luyindula, L. Tona, S. Lukembila, M. Tsakala, K. Mesia, C.T. Musuamba, R.K. Cimanga, S. Apers, T. De Bruyne, T. Pieters, A. Vlientick, "In vitro antiplasmodial activity of callus extracts from fresh apical stems of Phyllantus niruri L (Euphorbiaceous); Part 1". Pharm. Biol. 42(7): pp. 1-7, June 2004.

[17] N.R. Kikakedimau, N.S. Luyindula, P. Doumas, H. Mutambel', Y. Baissac, K.R. Cimanga, N.A. Diamuini, O.F. Bulubulu and C. Jay Allemand, "Phytochemical analysis of Phyllanthus niruri L. (Phyllanthaceae) extracts collected in four geographical areas in the Democratic Republic of the Congo". African Journal of Plant Science, Vol. 7(1): pp. 9 - 20, January 2013.

[18] J.B. Harborne, Phytochemical methods. Chapman and Hall. London; chap.1, pp. 1998.

[19] T.J. Mabry, K.R. Markham, M.B. Thomas, The systematic identification of flavonoids. Spring-Verlag, New York; 1970

[20] O. Leconte, J.P. Bonfils, Y. Bauvaira, "Protective effect of iridals from saponin injury in Candida albicans cells". Phytochemistry 44, pp. $575-579$, February 1997.

[21] A.E. Hagerman, "Radial diffusion Method for determining tannin in plant extracts". J. Chem. Ecol.13(3), pp. 437-449, March 1987.

[22] S. Peng and C. Jay-Allemand, "Use of antioxidants in extraction of tannins from valnut plants". J. Chem. Ecol, 17: pp. 887- 896, May 1991.

[23] X. Liu, J. Jia, X. Jing, and G. Li, “Antioxidant Activities of Extracts from Sarcocarp of Cotoneaster multiflorus. Hindawi Journal of Chemistry. pp. $1-7$, May 2018
[24] Y.C.F. Ladoh, S.D. Dibong, M.A. Nyegue, T.R.P. Djembissi, N.B Lenta, M.E. Mpondo, J. Yinyang, J.D. Wansi, "Antioxidant activity of methanolic extract of Phragmanthera capitata (Loranthaceae) from Citrus sinensis". Journal of Applied Biosciences, 84: 7636-7643, December 2014

[25] C. Quettier-Deleu, B. Gressier, J. Vasseur, T. Dine, C. Brunet, M. Luyckx, M. Cazin, J.C. Cazin, F. Bailleul, F. Trotin, "Phenolic compounds and antioxidant activities of buckwheat (Fagopyrum esculentum Moench) hulls and flour'. Journal of Ethnopharmacology Vol.72 (1-2): 35-42, October 2000.

[26] G. Marinova and V. Batchvarov, "Evaluation of the methods for determination of the free radical scavenging activity by DPPH Bulgarian Journal of Agricultural Science, 17 (1): pp. 11 - 24, January 2011.

[27] P. Molyneux, "The use of the stable free radical diphenylpicrylhydrazyl (DPPH) for estimating antioxidant activity". Songklanakarin J. Sci. Technol., 26(2): pp. 211-219, Mar.-Apr. 2004

[28] L.P. Leong and G. Shui, "An Investigation of Antioxidant Capacity of Fruits in Singapore Markets". Food Chemistry, 76(1), pp. 69-75, January 2002.

[29] J.-K. Moon and T. Shibamoto, “Antioxidant Assays for Plant and Food Components". J. Agric. Food Chem. 57(5): 1655-1666, January 2009.

[30] W. Trager and J.B. Jensen, "Human malaria parasites in continuous culture". Science, 193(4254):673-5, August 1976.

[31] D.J. Krogstad, I.Y. Gluzman, D.E. Kyle, A.M. Oduola, S.K. Martin, W.K. Milhous, PH Schlesinger, "Efflux of chloroquine from Plasmodium falciparum: Mechanism of chloroquine resistance". Science 238(4831): pp. 1283-5, November 1987.

[32] I. Ljungström, H. Perlmann, M. Schlichtherle, A. Scherf, M. Wahlgren, "Methods in malaria research". MR4/ATCC, Manassas, Virginia, Parasites, pp. 1 - 10, January 2004

[33] N.R. Kikakedimau, P. Doumas, H. Mutambel', N.A. Diamuini, O.F. Bulubulu, A.J. Kikalulu, N.S. Luyindula, and K.R. Cimanga (2012): Antiplasmodial activity and phytochemical analysis of Phyllanthus niruri L. (Phyllanthaceae) and Morinda lucida Benth (Rubiaceae) extracts. Journal of Agricultural Science and Technology A 2, pp. 373 - 383, March 2012.

[34] N.R. Kikakedimau, C. Franche and N.S. Luyindula (2015): Effetcs of Sodium azide on seeds germination, platlets growth and in vitro antimalarial activities of Phylla tnus odontadenius Müll. Agrg. American Journal of Experimental Agriculture 5(3): pp. 226 - 238, (published October 2014), 2015.

[35] R. Chaphalkar, K.G. Apte, Y. Talekar, O.S. Kumar, and M. Nandave, "Antioxidants of Phyllanthus emblica L. Bark Extract Provide Hepatoprotection against Ethanol-Induced Hepatic Damage: A Comparison with Silymarin". Hindawi Oxidative Medicine and Cellular Longevity, pp. 1 - 10, January 2017.

[36] N.R. Kikakedimau, M.D. Musuyu, M.K.O. Nsendo, P. Doumas, M.S Kahambu, K.M. Taba and N.S. Luyindula, "Correlation between Antioxidants and Antiradical Activities with In Vitro Antimalarial Activity of Phyllanthus odontadenius". Acta Scientific Medical Sciences, Vol.3 (7): pp. 144 - 154, July 2019.

[37] N.B. Arina and Abdul Rohman, "The phenolic contents and antiradical activity of Indonesian Phyllanthus urinaria L". International Food Research Journal, 20(3): pp. 1119 - 1124, (Accepted:11 December 2012), 2013.

[38] W. Vermerris and R. Nicholson, Families of Phenolic Compounds and Means of Classification in Phenolic compound. Chemestry Book, Springer Science, Gainesville, USA, 1 - 34pp, 2006.

[39] M. Naczk and F. Shahidi, "Extraction and Analysis of Phenolics in Food". Journal of Chromatography A, 1054 (1-2), pp. 95-111, October 2004.

[40] S.P. Wong, L.P. Leong and J.H. William Koh, "Antioxidant activities of aqueous extracts of selected plants". Food Chemistry 99(4):775-783, 2006.

[41] K.A. Tawaha, F. Alali, M. Al-Gharaibeh, M. Mohammad and T. ElElimat, "Antioxidant activity and total phenolic content of selected Jordanian plant species”. Food Chemistry 104(4): pp. 1372-1378, November 2007.

[42] R.A. Pérez, M.T. Iglesias, E. Pueyo, M. Gonzalez, C. de Lorenzo, "Amino acid composition and antioxidant capacity of Spanish honeys" J Agric Food Chem. 2007 Jan 24;55(2):360-5, 2007 ( publication Décember 2006).

[43] B. Halliwell: "Free Radicals and Antioxidants: A Personal View". Nutrition Reviews, 52(8): pp. 253 - 265, August 1994.

[44] N. Cotelle, "Role of Flavonoids in Oxidative Stress". Current Topics in Medicinal Chemistry, 1, pp. 569-590, 2001. 
[45] S. V. Jovanovic, S. Steenken, M. Tosic, B. Marjanovic, and M. G. Simic (1994): Flavonoids as Antioxidants. J. Am. Chem. Soc., 116, 11, pp. 4846-4851, June 1994.

[46] I. Atti: «Evaluation des activités antioxydant et antiradicalaire d'un mélange d'épices «Ras el hanout». Mémoire de Master Académique, Fac. des Sciences de la Nature et de la Vie. Université KASDI MERBAH Ouargla, Inédit, 61p, 2014. Références bibliographiques et Annexes exclus.

[47] H.Enneb, A. Belkhadi, F.Cheour, and A. Ferchichi, « Comparaison des composés phénoliques et du pouvoir antioxydant de la plante de henné (Lawsonia inermis L.) ». Journal of New Sciences, 20 (2) : pp. 788 - 793, August 2015.

[48] R. Batista, A.J. Silva Junior and A. Braga de Oliveira, "PlantDerived Antimalarial Agents: New leads and efficient phytomedicines. Part II. Non-Alkaloids Naturels Products ». Molecules 14: pp. 3037 - 3072, August 2009.

[49] J.B. Lekana-Douki, S.L. Oyegue Liabagui, J.B. Bongui, R. Zatra, J. Lebibi, F.S. Toure-Ndouo, "In vitro antiplasmodial activity of crude extracts of Tetrapleura tetraptera and Copaifera religiosa". BioMed central Research Notes 4:506 (1 - 5), November 2011.

[50] S. Ravikumar, S.J. Inbaneson and P. Sungnthi, "In vitro antiplasmodial activity of chosen terrestrial medicinal plants against Plasmodium falciparum". Asian Pacific Journal of Tropical Biomedicine, pp. 1-5, January 2012.

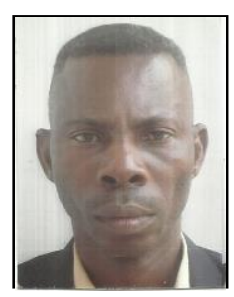

Kikakedimau Nakweti Rufin: 2015: $\mathrm{PhD}$ in Biology, Plant Molecular Biology, University of Kinshasa, Kinshasa/Democratic Republic of the Congo (DRC). 2007: DEA (Master Thesis) in Biology, Biotechnology, University of Kinshasa, Kinshasa/DRC. 2015 today: Associated Professor (Plant Physiology, General physiology, General biology, Structural biochemistry, Molecular genetics and Plant genetics and genetic engineering) at ISP/KENGE, Visiting Professor at the University of Kwango's Province (UNIK) and University of Kinshasa (UNIKIN). 2016 today: Researcher in CGEA/CREN-K, Division of life Sciences (specialist in medicinal plants breeding against malaria), September 2017 today: Head of Department of Biology-Chemistry, Section Sciences exacts/ISPKENGE.

Rufin publications (Some publications): (2018): Increasing secondary metabolites in Phyllanthus odontadenius M.A. (Book), Ed. Scholars'Press, Norderstedt, Germany, 150p. ISBN: 978-620-2-31328-5. (2018): Journalof Pharmaceutical Research International (JPRI), 21(2): 1 - 14. (2017): European Journal of Medicinal Plants, 18(3): pp. 1 - 10.

Prof. Dr. Rufin Kikakedimau Nakweti is a member of PANDA, Association of Kwango Teachers. 2016 (June 28 to July 18): participation to Workshop MooSciTic for intensification the competence of ProfessorResearchers from South, organized by IRD-CIRAD at IRBA/Cotonou (Benin). 2012 (November 19 - 28, 2012): Participation to the first workshop on formation in Plant Molecular biology and Genetic, organized for young researchers from West Africa, Dakar (Senegal). 2012 (November $04-08,2012$ ): Participation to regional AFRA/IAEA course (Training course) entitled: « Mutation Breeding Techniques and Handling of Mutated Populations » (C7-RAF-5.066-002), Cairo (Egypt). 2007 2008: (November 15, 2007 to April 15, 2008 (5 months of fellowship): "Fellowship on moderns techniques of Plant Biology (Plant Biotechnologies) in tissues Culture, molecular Biology, Plant cytology \& Plant histology", Plant Breeding and Genetics, Rhizogenesis Lab (UMRDIAPC), IRD/Montpellier in France. 2006 (August, 14 to September, 01): Participation to regional AFRA/IAEA course (Training course) entitled: «Molecular Marker Techniques for Development of Improved Crop Varieties», ARC/Roodeplaat, Pretoria, South Africa. 2018 (11 - 12 June 2018): Participation in the "4th International Conference and Exhibition on Natural Products, Medicinal Plants \& Marine Drugs", Topic: "Increasing of Secondary Metabolites Against Malaria by Mutagenesis" Theme: "Medicinal Development and Strategies of Natural Products", Rome, Italy. 2017 (11-13 September 2017): Participation as speaker (Subject: "INCREASING OF SECONDARY METABOLITES AGAINST MALARIA BY MUTAGENESIS") at the conference "Global Conference on Plant Science and Molecular Biology (GPMB-2017)" Valencia, Spain. 2017 (July 15, 2017): Participation in the Symposium on "Plants: Science and Applications" organized by ACASTI, Conference room / Sacré-Cœur de la Gombe, DRC. 